\title{
Paideusis
}

\section{Introduction: Philosophical Perspectives on Education for Well-Being}

\section{Thomas Falkenberg}

Volume 22, Number 2, 2015

Philosophical Perspectives on Education for Well-Being

URI: https://id.erudit.org/iderudit/1071454ar

DOI: https://doi.org/10.7202/1071454ar

See table of contents

Publisher(s)

Canadian Philosophy of Education Society

ISSN

0838-4517 (print)

1916-0348 (digital)

Explore this journal

Cite this document

Falkenberg, T. (2015). Introduction: Philosophical Perspectives on Education for Well-Being.Paideusis, 22(2), 1-7. https://doi.org/10.7202/1071454ar

(c) Thomas Falkenberg, 2015

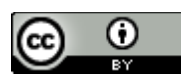

This document is protected by copyright law. Use of the services of Erudit (including reproduction) is subject to its terms and conditions, which can be viewed online.

https://apropos.erudit.org/en/users/policy-on-use/
This article is disseminated and preserved by Érudit.

Érudit is a non-profit inter-university consortium of the Université de Montréal, Université Laval, and the Université du Québec à Montréal. Its mission is to promote and disseminate research.

https://www.erudit.org/en/ 


\section{Introduction: Philosophical Perspectives on Education for Well-Being}

THOMAS FALKENBERG

Faculty of Education, University of Manitoba, Canada

This special issue of Paideusis focuses on "Philosophical Perspectives on Education for Well-Being." Well-being as a social and political concern - sometimes under the term "happiness" - has been put into greater spotlight in public discourse and public policy in recent years (e.g., Bok, 2010; Rose \& Rowlands, 2010; Stiglitz, Sen, \& Fitoussi, 2010), and a number of assessment tools to measure human well-being/quality of life have been developed at national and international levels, like the UN's Human Development Index, the OECD's Better Life Index, and the New Economics Foundation's Happy Planet Index. For the last few years the Canadian Index of Wellbeing (CIW) has been used to measure well-being of Canadians to provide a measure of social progress as alternative or complement to the sole economic measure of GDP (CIW, 2012).

Different academic disciplines have been contributing to the discourse on human well-being, including philosophy (e.g., Aristotle, trans. 1976; Griffin, 1986; Sumner, 1996), psychology (e.g., Diener, 1984; Kahneman, Diener, \& Schwarz, 1999; Seligman, 2011), and economics (Frey, 2008; Jackson, 2009; Layard, 2005), and a range of conceptualizations of well-being have been proposed (for a structured overview of Western approaches to well-being, see Falkenberg, 2014). Judging by my observation of the North American public discourse on well-being, approaches to well-being that have led to empirical studies with reportable "findings" on well-being, like those linked to positive psychology (e.g., Lopez \& Snyder, 2009), seem to have exerted much greater influence on public discourse and public policy concerning the school system than those that do not.

Philosophy has probably the longest tradition of all disciplines in dealing with the concept of well-being, providing a range of different conceptualizations (e.g., Griffin, 1986; Talbott, 2010), albeit sometimes under the use of a different term, like happiness (Almeder, 2000), the good life (Feldman, 2004), and welfare (Sumner, 1996). Philosophical perspectives on well-being seem to have a declining impact on public discourse, and this is mirrored in the declining role of philosophy of education in teacher education and education more generally (Clark, 2006), and in Canada in particular (Christou \& Bullock, 2013; Vokey, 2006). In education, a discourse has been building that gives privilege to the idea that educational practice should be guided by research that shows "what works" (for a critique of this discourse, see Biesta, 2007, 2010).

There is, however, one philosophical perspective on well-being that has been quite influential at the policy level: the Capabilities Approach. This approach to well-being has been developed by Armartya Sen (e.g., 1993, 2009) and Martha Nussbaum (e.g., 2000, 2011). Sen was a consultant on the creation of the very prominent Human Development Index of the United Nations (Saito, 2003, p. 22), and he was also a member of the Commission on the Measure of Economic Performance and Social Progress in France, established by former French President Nicolas Sarkozy for the purpose of considering the limitations of GDP as a measure of social progress and the feasibility of alternative assessment tools (Stiglitz, Sen, \& Fitoussi, 2010).

I want to use the Capabilities Approach to well-being to illustrate one way in which philosophical perspectives can contribute and, in the case of the Capabilities Approach, have actually

(C) Copyright 2015. The author, Thomas Falkenberg, assigns to Paideusis the right of first publication and educational and nonprofit institutions a non-exclusive license to use this document for personal use and in courses of instruction provided that the article is used in full and this copyright statement is reproduced. Any other usage is probibited without the express permission of the author. 
contributed to public discourse and policy on well-being. In a chapter on the philosophical influences on the Capabilities Approach, Nussbaum (2011, chapter 7) makes clear how much the political liberalism underlying the Capabilities Approach (as far as her particular version of the Approach is concerned) draws on Aristotelian political and ethical thought around human virtues and the Stoics' view of human equality and human dignity - ideas that she also locates in seventeenth and eighteenth century European philosophies. (Sen, on the other hand, draws more on Indian philosophers, like Rabindranath Tagore and Mahatma Gandhi, for his inspiration for the Capabilities Approach; see Nussbaum, 2011, pp. 123-124). One way in which philosophical perspectives can contribute to public discourse and policy on well-being is through the theories developed in the academic discipline of philosophy - Sen and Nussbaum are both academic philosophers. As Nussbaum suggests, the academic tradition of developing philosophical perspectives on, for instance, justice (e.g., Rawls, 1999) has been influential on the public discourse and policy on well-being through the Capabilities Approach. Political philosophy and ethics, two traditional fields of study in the academic discipline of philosophy, create an ongoing discourse on philosophical perspectives directly relevant to questions of well-being.

For reasons of principle, these theoretical philosophical perspectives are important for public discourse on well-being. Drawing on Tyrell, Schumacher (1999) distinguishes between convergent and divergent problems humankind faces (see also Schumacher, 1977, chapter 10):

G. N. M. Tyrell has put forward the terms 'divergent' and 'convergent' to distinguish problems which cannot be solved by logical reasoning from those that can. Life is being kept going by divergent problems which have to be 'lived' and are solved only in death. Convergent problems on the other hand are [humankind]'s most useful invention; they do not, as such, exist in reality, but are created by a process of abstraction. When they have been solved, the solution can be written down and passed on to others, who can apply it without needing to reproduce the mental effort necessary to find it.

(Schumacher, 1999, p. 75)

'What is the best method of education?' presents, in short, a divergent problem par excellence. The answers tend to diverge, and the more logical and consistent they are, the greater is the divergence.

(Schumacher, 1977, p. 123)

Theoretical philosophical perspectives on well-being can support us as individuals and as communities in our dealing with the divergent problems that unavoidably confront humankind at the individual and communal level - because those problems are the "perennial problems of philosophy," as Solomon (1999, pp. 10-13) characterizes the divergent problems. As Schumacher suggests, each generation and each individual will have to engage with the same divergent problems faced by previous generations and by the fellow human next to us as part of living our lives. Thus, divergent problems are at the centre of human well-being, and with them, then, theoretical philosophical perspectives that can help us address those problems. For instance, they can provide us with perspectives on the difference between happiness and meaningfulness, on the role of suffering in happy lives, on the concept of tragic joyfulness, and on the concept of the reflective life (see the contributions in Bortolotti, 2009).

Next to the theoretical philosophical perspectives developed in the academic context of doing philosophy, there is a second type of philosophical perspective on well-being that can potentially contribute to public discourse and policy on well-being: philosophical perspectives developed through the engagement with philosophy as a way of life (Hadot, 1995; Nehamas, 1998; Nussbaum, 1994; Shusterman, 1997; Solomon, 1999). Compared to doing philosophy as an academic discipline for the purpose of developing theories about well-being and related ideas, doing philosophy as a way of life is "a tradition that saw theory as a useful instrument to a higher philosophical practice: the art of living wisely and well" (Shusterman, 1997, p. 5). Philosophical perspectives on well-being from this tradition 
arise from and contribute to a person's well-being less through considering externally-developed theories on well-being and related ideas, and more through the process of philosophizing (for examples of such processes, see Bai, 2006). Philosophical inquiry as a "continual exercise in reinterpreting the experience of one's self and surroundings" (Shusterman, 1997, p. 15) is then not about establishing a systematic account of well-being that can hold up in the context of public discourse, but about the need and desire to handle life's on-going challenges to one's well-being through philosophical inquiry by the individual focused on the concrete challenges faced by that particular individual.

How can the approach of individuals engaging in philosophical inquiry as an "art of living wisely and well" (Shusterman, 1997, p. 15) be a way of developing philosophical perspectives on well-being that can potentially contribute to public discourse and policy on well-being? This approach can serve such a purpose if and when those engaging in philosophy as a way of life engage with each other appreciatively and supportively. One of the articles in this special issue, I suggest, is exemplifying one form of such engagement (see below).

The discussion so far transfers, or better extends, easily into the study of education for well-being. Although they are by far outnumbered by psychologically-oriented perspectives on education for wellbeing, theoretical philosophical perspectives on education for well-being have always been part of the philosophical tradition, be it Western philosophical perspectives on well-being and education (Brighouse, 2008; Hostetler, 2011; White, 2011) or Eastern traditional approaches to holistic education (Nakagawa, 2000). To reference the above example of the Capabilities Approach to well-being again, there has recently been increased interest in seeing this approach utilized as a theoretical philosophical perspective on education for well-being (e.g., Biggeri, Ballet, \& Comim, 2011; Fegter \& Richter, 2014; Hart, Biggeri, \& Babic, 2014).

Philosophy as a way of life also contributes perspectives on education for well-being. For instance, Bai (2006) suggests a number of specific practices of philosophizing as "an art of living" (p. 7) that have the potential to contribute to the "cultivation of fundamental human agency" (p. 8) and, I suggest, to education for well-being.

\section{This Special Issue}

Knowing of my involvement with the interdisciplinary research group on education for sustainable well-being at the University of Manitoba, Daniel Vokey and Claudia Eppert - the former Editors-in-Chief of Paideusis - suggested to me the possibility of a special issue on education for wellbeing in Paideusis. I happily took them up on this opportunity and would like to thank them through this venue as well for their encouragement and support. Without their doing, this special issue would not have happened.

I want to express my appreciation to all those colleagues who submitted an abstract for consideration for this special issue and particularly to those who developed those abstracts into fullfledged papers by invitation. In the end, of those submitted papers with a somewhat unfortunate combination of time constraints and peer-review, three are making up this special issue.

The article by Cardinal, Lambert, and Lamouche explores the role of culture in educating for well-being, drawing on the three authors' personal experiences with "attending to well-being and culture in educational research and policy creation" (Cardinal, Lambert, \& Lamouche, this volume, p. 8). Their article illustrates philosophizing as a way of life. They use collaborative narrative inquiry to "travel each other's worlds with loving perception" (p. 9). The authors first "listen" to the narratives of the others as a first step in such travel, followed by an appreciative and supportive engagement with the others' cultural worlds ("with loving perception"), helping each of them to develop a deeper understanding of their own cultural embeddedness.

Philosophical perspectives from the stance of philosophical inquiry as a way of life also provide help if we want to go beyond the context of friendship and collegiality. For instance, Vokey's (2001) 
proposal for a "moral discourse in a pluralistic world" proposes a framework for discourse based on a more rational engagement with others, while Scott's $(2011,2014)$ approach using the Buberian concept of dialogue proposes such dialogue as "a state of being, an ontological turning toward the other made possible through the perception of the other as Thou" (Scott, 2014, p. 327, emphasis in original).

McMillan's article engages with what is probably one of the most philosophical issues around the concept of well-being and its educational use, namely the questions "Whose concept?" and "Whose judgment?" (Falkenberg, 2014, pp. 86-88). Positive psychology, the label of the currently most influential cluster of scholarly work on the practice of education for well-being (Linley \& Joseph, 2004), has been challenged for its neglect of these questions. Christopher and his collaborators (Christopher, 1999; Christopher \& Hickinbottom, 2008; Christopher, Rochardson, \& Slife, 2008) have been criticizing the aim of positive psychology to develop a concept of the good life that goes beyond specific cultural interpretations of the good life and have argued that the concept of self which underlies positive psychology "is based largely on dominant Western, and particularly American, ideologies of 'individualism' or 'liberal individualism"' (Christopher \& Hickinbottom, 2008, p. 566).

McMillan's article in this special issue contributes two perspectives to this philosophical question. The first is the Inuit philosophy Inuit Qaujimajatuqangit, which is a worldview for living a good life, based on four laws and six principles (McMillan, this volume). The Inuit approach to the good life expressed in these laws and principles, the reader will quickly recognize, are in diametrical opposition to what Christopher and Hickinbottom (2008) have called the "dominant Westerns . . . ideologies of 'individualism and "liberal individualism"' (p. 566).

The second philosophical perspective we can gain from McMillan's article is the perspective on how challenging and constrained cross-cultural understanding is. Very much in the spirit of Cardinal et al.'s contribution to this special issue, McMillan engages with the other's cultural world "with loving perception." Her article will make a valuable contribution to the philosophical discourse about the challenges of, but also constrained possibilities for "two-eye seeing" (a) by embedding the issues into a concrete context of educational policy and practice that is of great moral importance to Canadian society, and (b) by discussing approaches that might make such two-eye seeing possible, at least sufficiently well-enough to make a difference in the struggle for "cultural survival in Nunavut" (McMillan, this volume).

While Cardinal et al. demonstrate in their contribution the process of engaging with each other's cultural word and McMillan discusses the challenges of such a process, Blom, Lu, and Mgombelo's contribution to this special issue invites the reader to actually take on the perspective of a "cultural world" that will, I suspect, present quite a different worldview from those held by most readers of Paideusis: a worldview shaped by traditional Eastern thought, particularly Buddhist philosophy.

A number of Canadian philosophers of education have been promoting perspectives from Eastern traditional philosophies in the philosophical discourse in Canada and beyond (e.g., Bai, 2001; Eppert, 2013; Orr, 2002; Vokey, 2008). Blom et al. (this volume) contribute to this endeavour. Their article takes its starting point in the seemingly widespread understanding in Canada of the role of recess in the school system, namely as the place where play is allowed before students get back to the serious business of being educated. The authors argue for an "Eastern concept of well-being," from which they develop a metaphysical notion of play. The authors argue that play in an educational context like schooling should go beyond the constraints of recess and that its place should be more centre-stage in the endeavour of education for well-being.

The article by Blom et al. will challenge many readers of Paideusis because it draws on a worldview and corresponding language that may be quite unfamiliar. But if the reader engages with the other's cultural world "with loving perception" - as Cardinal et al. suggest and exemplify - much good might come from it, maybe in the form of a clearer vision in our "two-eye seeing." 


\section{References}

Almeder, R. (2000). Human happiness and morality: A brief introduction to ethics. Amherst, NY: Prometheus Books.

Aristotle (1976). The ethics of Aristotle: The Nicomachean ethics. (J.A.K. Thomson, Trans.; rev. ed.). London: Penguin.

Bai, H. (2001). Beyond the educated mind: Towards a pedagogy of mindfulness. In B. Hocking, J. Haskell, \& W. Linds (Eds.), Unfolding bodymind: Exploring possibility through education (pp. 86-99). Brandon, VT: Foundation for Educational Renewal.

Bai, H. (2006). Philosophy for education: Towards human agency. Paideusis, 15(1), 7-29.

Biesta, G. (2007). Why 'what works' won't work: Evidence-based practice and the democratic deficit in education research. Educational Theory, 57(1), 1-22.

Biesta, G. (2010). Why 'what works' still won't work: From evidence-based education to value-based education. Studies in Philosophy and Education, 29, 491-503.

Biggeri, M., Ballet, J., \& Comim, F. (Eds.). (2011). Children and the Capability Approach. Houndmills, UK: Palgrave Macmillan.

Bok, D. (2010). The politics of happiness: What government can learn from the new research on well-being. Princeton, NJ: Princeton University Press.

Bortolotti, L. (Eds.). (2009). Philosophy and happiness. Houndmills, UK: Palgrave Macmillan.

Brighouse, H. (2008). Education for a flourishing life. In D. Coulter \& J. Wiens (Eds.), Why do we educate? Renewing the conversation (pp. 59-71). Malden, MA: Blackwell.

Canadian Index of Wellbeing. (2012). How are Canadians really doing? The 2012 CIW Report. Waterloo, ON: Canadian Index of Wellbeing and University of Waterloo. Retrieved from the CIW website: http://uwaterloo.ca/canadian-index-wellbeing

Christopher, J. C. (1999). Situating psychological well-being: Exploring the cultural roots of its theory and research. Journal of Counseling \& Development, 77, pp. 141-152.

Christopher, J. C., \& Hickinbottom, S. (2008). Positive psychology, ethnocentrism, and the disguised ideology of individualism. Theory \& Psychology, 18(5), 563-589. doi: 10.1177/0959354308093396

Christopher, J. C., Richardson, F. C., \& Slife, B. D. (2008). Thinking through positive psychology. Theory \& Psychology, 18(5), pp. 555-561. doi: 10.1177/0959354308093395

Christou, T. M., \& Bullock, S. M. (Eds.). (2013). Foundations in teacher education: A Canadian perspective. Ottawa, ON: Canadian Association for Teacher Education. Retrieved from the website of CATE: http://www.csse-scee.ca/associations/about/cate-acfe

Clark, J. (2006). Philosophy of education in today's world and tomorrow's: A view from 'down under'. Paideusis, 15(1), 21-30.

Diener, E. (1984). Subjective well-being. Psychological Bulletin, 95(3), 542-575.

Eppert, C. (2013). Awakening education: Toward a rich tapestry of mindful and contemplative engagement for social/environmental transformation. In J. Lin, E. Brantmeier, \& R. Oxford (Eds.), Re-envisioning higher education: Embodied pathways to wisdom and social transformation (pp. 337351). Charlotte, N.C.: Information Age Publishing

Falkenberg, T. (2014). Making sense of Western approaches to well-being for an educational context. In F. Deer, T. Falkenberg, B. McMillan, \& L. Sims (Eds.), Sustainable well-being: Concepts, issues, and educational practices (pp. 77-94). Winnipeg, MB: ESWB Press. Retrieved from www.ESWBPress.org

Fegter, S., \& Richter, M. (2014). Capability approach as a framework for research on children's wellbeing. In A. Ben-Arieh, F. Casas, I. Frønes, J. E. Korbin (Eds.), Handbook of child well-being: Theories, methods and policies in global perspective (pp. 739-758). Dordrecht, The Netherlands: Springer.

Feldman, F. (2004). Pleasure and the good life: Concerning the nature, varieties, and plausibility of hedonism. Oxford, UK: Clarendon Press.

Frey, B. S. (2008). Happiness: A revolution in economics. Cambridge, MA: MIT Press. 
Griffin, J. (1986). Well-being: Its meaning, measurement and moral importance. Oxford: Clarendon Press.

Hadot, P. (1995). Philosophy as a way of life: Spiritual exercises from Socrates to Foucault (A. I. Davidson, Ed.). Oxford: Blackwell.

Hart, C. S., Biggeri, M., \& Babic, B. (2014). Agency and participation in childhood and youth: International applications of the Capability Approach in schools and beyond. London: Bloomsbury.

Hostetler, K. D. (2011). Seducing souls: Education and the experience of well-being. New York: Continuum International Publishing Group.

Jackson, T. (2009). Prosperity without growth: Economics for a finite planet. London: Earthscan.

Kahneman, D., Diener, E., \& Schwarz, N. (Eds.). (1999). Well-being: The foundations of hedonic psychology. New York: Russell Sage Foundation.

Layard, R. (2005). Happiness: Lessons from a new science. London: Penguin Books.

Linley, P. A., \& Joseph, S. (Eds.). (2004). Positive psychology in practice. Hoboken, NJ: Wiley \& Sons.

Lopez, S. J., \& Snyder, C. R. (Eds.). (2009). The Oxford handbook of positive psychology (2nd ed.). Oxford, UK: Oxford University Press.

Nakagawa, Y. (2000). Education for awakening: An Eastern approach to holistic education. Brandon, VT: Foundation for Educational Renewal.

Nehemas, A. (1998). The art of living: Socratic reflections from Plato to Foucault. Berkley, CA: University of California Press.

Nussbaum, M. C. (1994). The therapy of desire: Theory and practice in Hellenistic ethics. Princeton, NJ: Princeton University Press.

Nussbaum, M. C. (2000). Women and human development: The Capability Approach. Cambridge, UK: Cambridge Universtity Press.

Nussbaum, M. C. (2011). Creating capabilities: The Human Development Approach. Cambridge, MA: The Belknap Press of Harvard University Press.

Orr, D. (2002). The use of mindfulness in anti-oppressive pedagogies: Philosophy and praxis. Canadian Journal of Education, 27(4), 477-490.

Rawls, J. (1999). A theory of justice (rev. ed.). Cambridge, MA: The Belknap Press of Harvard University Press.

Rose, W. \& Rowlands, J. (2010). Introducing the concept of child well-being into government policy. In C. McAuley \& W. Rose (Eds.), Child well-being: Understanding children's lives (pp. 67-89). London: Kingsley Publishers.

Saito, M. (2003). Amartya Sen's Capability Approach to edcuation: A critical exploration. Journal of Philosophy of Education, 37(1), 17-33.

Schumacher, E. F. (1977). A guide for the perplex. New York: HarperPerennial.

Schumacher, E. F. (1999). Small is beautiful: Economics as if people mattered. Point Roberts, WA: Hartley \& Marks Publishers. (First published 1973)

Scott, C. (2011). Becoming dialogue: Martin Buber's concept of turning to the other as educational praxis. Unpublished doctoral dissertation, Simon Fraser University, Burnaby, British Columbia.

Scott, C. (2014). Buberian dialogue as an intersubjective contemplative praxis. In O. Gunnlaugson, E. W. Sarath, C. Scott, \& H. Bai (Eds.), Contemplative learning and inquiry across disciplines (pp. 325-340). Albany, NY: State University of New York Press.

Seligman, M. E. P. (2011). Flourish: A visionary new understanding of happiness and well-being. New York: Free Press.

Sen, A. (1993). Capability and well-being. In M. C. Nussbaum \& A. Sen (Eds.), The quality of life (pp. 3053). Oxford, UK: Clarendon Press.

Sen, A. (2009). The idea of justice. Cambridge, MA: The Belknap Press of Harvard University Press.

Shusterman, R. (1997). Practicing philosophy: Pragmatism and the philosophical life. New York: Routledge.

Stiglitz, J. E., Sen, A., \& Fitoussi, J.-P. (2010). Mismeasuring our lives: Why GDP doesn't add up. New York: The New Press. 
Solomon, R. C. (1999). The joy of philsophy: Thinking thin versus the passionate life. Oxford, UK: Oxford University Press.

Sumner, L. W. (1996). Welfare, happiness, and ethics. Oxford, UK: Oxford University Press .

Talbot, W. J. (2010). Human rights and buman well-being. Oxford, UK: Oxford University Press.

Vokey, D. (2001). Moral discourse in a pluralistic world. Notre Dame, IN: University of Notre Dame Press.

Vokey, D. J. (2006). What are we doing when we are doing philosophy of education. Paideusis, 15(1), 4555.

Vokey, D. J. (2008). Hearing, contemplating, and meditating: In search of the transformative integration of heart and mind. In C. Eppert \& H. Wang (Eds.), Cross-cultural studies in curriculum: Eastern thought, educational insights (287-312). New York: Lawrence Erlbaum.

White, J. (2011). Exploring well-being in schools: A guide to making children's lives more fulfilling. London: Routlege.

\section{About the Author}

Thomas Falkenberg is an associate professor in the Faculty of Education at the University of Manitoba. He is the current Coordinator of the Education for Sustainable Well-Being Research Group of the University of Manitoba (www.eswbrg.org). More details about his research and academic background can be gleaned from http://home.cc.umanitoba.ca/ falkenbe/index.html. 